\author{
SABINA LUCYNA ZALEWSKA* \\ Warsaw, Poland \\ ORCID ID oooo-0002-9081-343X
}

\title{
SYMPTOMS OF DEPRESSION IN CHILDREN PART OF THE "SNOWFLAKE" GENERATION AND THEIR INPUT FOR THE FUNCTIONING OF THE WHOLE FAMILY. NARRATIVE RESEARCH OF MODERN FAMILIES
}

\begin{abstract}
In the article I analyze the problem of mental health about children of the generation of „snowflakes”. The subject of the article is the problem of child depression affecting the whole family system. The main symptoms of this disease are presented. They are discussed in detail with their impact on family relationships. The main functions of the family were recalled, as they gave the structure for the analysis of narrative tests. A lot of attention was paid to the description of the impact of depression on the life of the whole family, including marriage, contact with children, social contacts, changes in the family's activity and material situation, as well as emotional reactions of family members. The analysis of narrative tests shows the family's reactions to the child's disease.
\end{abstract}

Keywords: generation of „snowflakes”, mental health problem, disease, depression, family, dealing with depression, the effects of depression in the family, narrative research.

\section{Introduction}

A family is of great value, this truth is commonly known. Unfortunately, every family lives through some difficult moments, which can be a big trial for every member of the family. Such a situation is every serious or chronic illness, which with suffering can be a real school of life.

A family is a complicated structure. Nothing, which occurs with only one member involved, doesn't affect the other people in the family. This phenomenon is in fact obvious and in line with the earliest folk wisdom: when it comes to our

* Dr Sabina Lucyna Zalewska, pedagog, psycholog rodziny, doktor nauk społecznych. Ekspert Fundacji Mamy i Taty oraz terapeuta w Archidiecezjalnej Poradni Dewajtis. Współpracuje z Mazowieckim Centrum Psychoterapii. 
mental well-being we are nearly exactly in the same condition as our family. In terms of our family we are a system of communicating vessels. There is something mysterious and unusually important in the functioning of family relationships. People who are close to one another can in fact become the cause of problems and often suffering, but from a different perspective they can also be a support and source of strength for themselves. Therefore when a serious illness occurs within the family, it effects every person in the family and wakes up various processes.

In the article I will try to characterize the so-called generation of "snowflakes" and the topic of illness in the family. I will focus on depression, of which 350 million people worldwide suffer from (World Health Organization 2018), on average every tenth person on our globe. According to WHO estimates, in the year 2020, depression can be the second most serious healthcare problem in the world (second to circulatory system problems). The subject of this serious and rapidly growing disease seems interesting from the family point of view and how depression not only affects a specific person, but how it can have an effect on the entire family system.

Nearly $2 \%$ of children are diagnosed with depression (it can affect both boys and girls equally) and even up to $8 \%$ of teenagers (girls suffer more often than boys at this age). It is estimated that widely understood depressive disorders may occur among $20 \%$ of teenagers and some sources say that depressive symptoms are found in nearly every third teenager. (Kendall 2004, p. 23-39)

\section{Characteristics of the "snowflake" generation}

Over the centuries, there were a few select different types of generations. They are called and characterized differently, rightfully noticed by Martyna Wójcik (Wojcik 2016), who specializes in marketing and advertisements. Concepts of generation "X", "Y" (millennials) and "Z" have been implemented by sociologists as well as psychologists. Mostly to separate and differentiate groups of society, which characterize in different behaviors, depending on when their participants were born. Who and what are people of generations "Y", "Z" in other words "snowflakes" or "all inclusive"? What are their personality traits and how can you recognize them in society? As parents (belonging to generation $\mathrm{X}$ and older $\mathrm{Y}$ ), how can we communicate with them, so that they understand us better?

As written by Roman Lorens (Lorens, 2020), specialist in educational law, multiyear "Y" generation also known as Millennials - generation of people born in the 8 os (older generation) and gos (younger generation) of the XX century. It's the first generation, which from the days they were born knew about the existence of the internet. Generation "Y", unlike their parents or grandparents, didn't have to fight for anything. They don't have anything to rebel against, because their parents have provided them with everything that could be good for them: a good education, comfortable lifestyle, freedom to travel and experience the world. At times they are known as the generation of the internet - they take in everything related to 
technology really fast, they are able to build basically a new world on this knowledge and they can move around and use it with ease.

Generation " $Z$ " is the generation of people born after the year 2000. They are people who don't know what life was like without the Internet and life before Poland joined the European union. Representatives of the generation "Z" don't know a reality without one filled with social media, the internet or technological innovations. They mostly live in a virtual world and constantly move, trying to catch up with the speed and tempo that the world is developing and moving at. They show to be people with good practical skills and ones that are sober minded. In addition to that, they are ambitious, sure of themselves and hungry for knowledge. They have connections and friends all around the world. English is their second language. They don't seem to engage in long term, deep friendships and relationships, it is difficult to interest them by a single topic for a longer duration of time. They lack social interpersonal skills and aren't the best at forming deeper more engaging and time consuming relationships.

The generation of "snowflakes" was created by overprotection and foresight of their parents. It is a generation that is made of very dependent, timid young people, who are unable to take care of problems regarding everyday life. The term snowflakes regards the people who have a low mental condition, who react really emotionally in regards to the environment surrounding them, for example changes in politics or the social situation, said by prof. Jonathan Haidt (Haidt, 2006, p. 37-39) from the University of New York. He explains that, the most straight-forward reason for this is the introduction of social media websites. Between 2009 and 2011 social life of teenagers changes from face to face contact to a virtual contact through a screen. In the year 2012 everyone is online. Soon after, especially among young women, the depression, anxiety, self-harm, suicides and eating-disorders rates drastically rose.

Overprotective parents allow their children to have a perfect environment, depriving them of the ability to experience defeat, and making sure they feel unique. This is why the young generation isn't able to take in any criticism whatsoever and when it's there they take it really badly.

The paradox and the difficulty arise from the fact that this generation, conventionally called "X”, or 500 plus, brings up the „Y” and "Z” generation, aged 6-22 years. Seeing the world of these generations is radically different. And although it does not look very bad arithmetically, there is an unimaginable gap between these two generations technologically and mentally. The lack of this understanding between the generations causes that children cannot cope mentally with emotional problems. Their parents, however, do not know how to reach them. They cannot speak their language, they do not understand their inner world. This whole difficult situation has many repercussions in terms of mental health. 


\section{The most characteristic symptoms of depression and their impact on the functioning of the family.}

We often use the term "depression" in everyday language to describe malaise, decreased activity, or prolonged sadness or feeling down. These are not sufficient conditions for the use of the term in question in the field of medicine or psychology. Referring to the introduction of one of the textbooks addressed to therapists and dealing with depression, we will read that „clinical depression (sometimes also called major depression) is a condition in which persistent depressed mood or loss of interest occur together with other credible somatic and mental signs, such as difficulties with sleep, poor appetite, impaired concentration, a sense of hopelessness and worthlessness "(Wielgus 2017, pp. 158-161.). Clinical depression is diagnosed on the basis of specific symptoms, their severity and duration. The diagnostic criteria are very precisely defined in the ICD-10 (World Health Organization) and DSM-5 (American Psychiatric Association) classifications used by clinicians.

Depression in the developmental period often coexists with other dysfunctions, especially behavioral disorders, anxiety disorders, dysthymia, ADHD and substance abuse (Rabe-Jabłońska, 2004, pp. 45-56). Depending on the context of the occurrence of depressive symptoms, affective disorders, behavioral and emotional disorders, somatogenic or post-traumatic disorders are diagnosed. Affective disorders may take the form of a single episode of major depression, recurrent major depression, dysthymia (Spence, Reinecke 2005, pp. 23-41).

There are few clinical trials on the treatment of depression in children and adolescents, so to date, doctors rely on the results of studies conducted in adults. These mainly relate to pharmacotherapy. The effectiveness of antidepressants in children and adolescents treatment requires further analysis. Pharmacotherapy is very often necessary in the treatment of severe depression in hospital conditions. In cases of mild to moderate depression, children are referred to individual, group or family therapy.

Individual therapy with young patients is practically impossible, so their parents also take part in it. Caregivers learn how to deal with a child suffering from depression. Young children usually benefit from group therapy that takes the form of play. Toddlers learn to connect with their peers and deal with emotions. Group therapy may also prove useful for adolescents who find defiant behavior hampers interpersonal relationships. Moreover, scientific research confirms the effectiveness of the treatment of mild and moderate depression during cognitivebehavioral and interpersonal therapy - similarly to adults (Kennedy, Lam, Nutt, \& Thase 2010, pp. 19-34).

Depression is a chronic and recurrent disease, therefore its treatment takes a long time, and after the first depressive episode there is a serious risk of another. Children with mild and moderate depression are most often treated at mental health clinics. 
It is difficult to recognize the symptoms characteristic of a child without being a therapist. Parents think then that their wrong educational approach causes changes in the child's behavior. They don't attribute it to the disease. Symptoms of depression in a child that change family life are (Kołodziejek 2008, pp. 17-19):

1. Withdrawal from Contact - withdrawal from social, class and school life and a significant reduction in contact with peers. It is difficult for parents to persuade their child to go out with their peers or invite some of their child's friends to their home.

2. Apathy - manifested by the loss of the ability to experience joy. The child stops enjoying himself. Nothing makes him happy. Parents do not understand this change. They often attribute it to social failure in a group or falling in love without reciprocity.

3. Depressive thinking - „Everything is pointless”, „I can't do anything anyway”. It is also manifested by low self-esteem: „I am hopeless, inferior, unattractive, stupid". An irrational pessimistic assessment of reality, one's own abilities and the future appears. These are difficult symptoms for the family. Often, parents try to reward their child for these feelings by directing their attention to objects. They buy their children expensive gifts or organize trips abroad.

4. Overwhelming sadness - in children and teenagers, high irritability is very common. The child easily develops extreme emotions (anger or despair). May demonstrate hostility and aggression towards the environment. Most often it provokes discouragement from making contact with him. In such a situation, families reach for psychological and therapeutic help. They cannot cope on their own with changing a child's emotions.

5. Hypersensitivity to criticism - excessive reaction to comments. The child reacts with despair or great anger even when brought to his attention in a very delicate way and it concerns a trivial matter. Parents often adopt two attitudes. They attribute it to the development phase, adolescence and growing-up. Sometimes they blame themselves in the educational sphere. They blame themselves for this change, they treat it as an educational mistake they made. Siblings often lose touch with each other. Healthy children move away from the ill ones.

6. Feeling of uselessness - there is excessive blame even for those events and circumstances that are beyond our control (e.g. conflict between parents, disagreements in the classroom, malaise of friends). These depressive behaviors make the family amused first. However, when the parents last for a long time, they seek the help of a specialist, fearing that it will get worse.

7. Discouragement - significant reduction or cessation of activities that were previously important or pleasant (e.g. fun, hobbies, meeting peers). There may also be a reluctance to take up daily duties or a complete abandonment of them. Very often, children refuse to get up in the morning, go to school, 
leave the house, and in extreme cases - from their room. They neglect personal hygiene and school work/ studying. Such behavior in the family is initially accepted as acting against the family and its rules. Parents become aggressive and coercive towards the child. They often blame it on bad upbringing and their parenting mistakes. Rarely, without the help of a specialist, they notice symptoms of depression in it.

8. The feeling of internal tension - then there is the feeling of anxiety. Depressive disorders are often accompanied by anxiety - almost constant, of constant intensity, undefined - it is difficult to identify, the cause or object of such anxiety. The child repeats: „I don't know what I'm afraid of”. Such behavior worries parents very much. They don't understand him. They try to find appropriate help for the child. They consult a psychiatrist.

9. Impulsive actions - there are ill-considered actions and justifications such as: „I don't care about anything anyway”. The child begins to drink alcohol, to use psychoactive substances (drugs, „legal highs”). He does this often to relieve anxiety, tension, and sadness. This behavior is discovered by parents very late. Oftentimes, siblings notice much earlier. When it is found out or discovered, parents are often unable to deal with it. At the climax, they seek help from a specialist.

10. Autoagressive actions - these activities include the recently observed ones: self-harm (deliberately damaging the body by cutting oneself with sharp objects, burning oneself with a lighter, cigarette, scratching, biting, etc.), deliberate pain, taking excessive drugs in order to „poison oneself „(but not in order to take one's own life). It is very difficult for parents to notice these changes. The child often hides them. Most often, school or peers tell parents about this. Parents feel helpless. They don't know what steps they should take. They often blame themselves. They use the help of school psychologists or therapists.

11. Thoughts of resignation - thoughts like: „life is meaningless”, „what am I living for" and fantasies about death: „what would happen if I died?", "Others would be better if I wasn't there". At first, parents ignore these words. They relate them to the difficult developmental period in which the child is at. However, as the child repeats it like a mantra over time, they get scared. Fear makes them seek help from specialists. They also, feeling helpless, look for help for themselves.

12. Suicidal thoughts - this manifests itself in thinking, fantasizing about taking one's own life. There are also suicidal tendencies, i.e. planning or making preparations for committing suicide, and in extreme cases - suicide attempts, i.e. taking direct actions aimed at taking one's own life. Siblings discover these symptoms first. The siblings don't always know how to go about doing something about it. They are worried about their relationship with the ill person and feel like they're forced to be loyal to their siblings. 
However, it weighs heavily on them. It causes changes in their behavior. When the situation comes to light, parents must take care of the sick and healthy child. This often causes them to become tired and apathetic. They cannot cope with this situation. They blame each other for the situation. It is at odds with their marital relationship. It contributes to the exacerbation of conflicts.

The less spectacular, but also disturbing symptoms include:

13. Concentration issues and difficulties with remembering things - often result in learning difficulties and poor school performance. The child may skip school. There is a discouragement from school, skipping lessons and frequent truancy. Parents associate these symptoms with educational problems. They do not try to explain the causes of this situation, they rather want to remedy the consequences. They often blame each other for the situation. This leads to conflicts in their marriage caused by these outcomes.

14. Mental awakening - often results from experienced fear and tension. The child fidgets, cannot focus on a specific activity, takes pointless actions without knowing it, e.g. nibbles at clothes, blurs a piece of paper with a pen, bites nails. This symptom is often misdiagnosed as ADHD. Parents cannot cope with these child's behaviors. They often ask for diagnosis and guidance in dealing with it. If a child is misdiagnosed, working with him or her is not producing the desired results, which frustrates the parents.

15. Excessive doings - taking up some activities in excess, e.g. playing computer games, watching TV, browsing information in a mobile phone. These symptoms are not obvious. Parents treat them as a child's social changes, fashion. Then they try to cut off the child from the source of arousal. Which most often causes aggression in a child that parents cannot control. They feel frustrated and helpless. When the emotions of a sick child culminate, they start seeking help from a specialist.

16. Change in appetite - increase or decrease in appetite, and as a result changes in body weight. This symptom is most often misdiagnosed. Parents' concerns tend to be anorexic or overweight. They are mainly attributed to eating disorders and the behavior of parents is related to those illnesses. Only a good specialist is able to guide parents on the right path of the disease. However, this happens very rarely or after long-term and unsuccessful treatment for an eating disorder.

17. Sleeping problems - difficulty with falling asleep, waking up at night, waking up early in the morning or excessive sleepiness. Drowsiness disorders cause notorious fatigue and distraction. This symptom is complex. Rarely diagnosed for depression unless associated with other symptoms. It causes excessive fatigue in the whole family. Often, parents try to accompany a sick child, they do not sleep at night. After prolonged symptoms, they seek help 
from a specialist. This often ends with the pharmacological prevention of the effects, that is, sleeping pills. However, this does not solve the problem.

\section{Research and methodology}

The narrative material (biographical narratives) presented in this article was collected during the research. The research was conducted at the turn of 2013-2015 and 2020-2021. The research group I had direct contact with were people who reported to the Catholic Center for Psychological and Pastoral Assistance Poradnia Dewajtis or took part in workshops for married couples in need of support, conducted by me as a part of the clinic's activities. The people for the study were deliberately selected from all people reporting to me at the clinic or participating in the workshops. Those whose children suffered from depression were selected. From the entire group, 41 married couples were selected for the study.

The following methods were used in the research:

1. method of narration: an overarching category that organizes the life of every person who builds his own identity by telling others about himself, establishes relations with others and acquires knowledge about the world;

2. method of biographical narrative: narratives referring to one's own life experience, biography, difficult events, successes and failures.

The questions I wanted to answer were: How does child depression interfere with basic family functions? What difficulties does a family with such a ill child face? What emotions do family members feel? How is the family coping with the new difficult situation for them?

\section{Presentation and analysis of family narratives}

Every serious illness, including depression, which is the subject of this study, affects the functioning of the family. This influence is multifaced and the disease affects the entire family system, all its members. What most describes the family, and what researchers focus on, is the structure and functions of the family.

Maria Ziemska distinguished the functions of the family and classified them (Ziemska, 1980, pp. 29-38). According to her classification, these functions include: procreation, economics, care and education, socialization and psychology. Based on this classification, a description of the impact of depression on family life will be presented.

\subsection{Disorders of the procreative function}

In this function, the family is perceived as a kind of group of people creating a specific type of community. Through biological processes, it contributes to the nourishment of this community by newborns. They belong both to the smaller part 
of it, which is the family, and to the general public. Thanks to biological processes, the group is fed with new people at the same time, as well as ensuring the creators, i.e. husband and wife, to satisfy their sex drive.

Anna and Wojtek (Married for 15 years):

I remember our fear, when we found out, that we were going to have a second child. Since Julia was ill. She had depression. Will the latter child be healthy? We had to go through so much with Julia. We are still going through it. Throughout our pregnancy, we worried that the other would be the same. We couldn't really enjoy our new baby. We were tired and frustrated. Specialists comforted us that it does not have to be the same with the other one. Nobody gave us a guarantee. We kept imagining the worst (Anna is crying)... Luckily, Krzyś is healthy. However, we look at him every day with fear that something may surface . Julia is taken care of. It is different. Nevertheless, we already cope with this disease better than we used to.

Magdalena and Adam (Married for 9 years):

Perhaps you will say that we are weird. Maybe. We are afraid to have a second child. (Adam says angrily. Staś' disease was like a thunderbolt from a bright child for us. After all, a child cannot be depressed, it is too small (Magdalena screams with tears in her eyes). All this is beyond us. We do not understand it. Afraid of a new pregnancy, not coping with this situation, we stopped sleeping together. We do not touch each other anymore. We forgot what intimacy is. We focus on Staś and we are afraid of a new situation.

The spouses have a disturbed reproductive function due to the child's illness. They are frustrated and tired. They feel the fear of a new baby and the fear that it will be sick like their existing child. It also affects their sex life and marital intimacy. The main feeling that prevails in them is the fear so that the situation wouldn't happen again.. So that they didn't have to go through the same.

\subsection{Disturbances within the economic function}

This function allows the material needs of the family to be met. Each family consists of people who raise funds for its maintenance. Thanks to their activity, the family can function as a whole, together they form a household. Through paid employment, family members provide material resources to meet various needs, e.g. housing, education, food, health protection, use of cultural goods and recreation.

Maria and Stanisław (Married for 20 years): 
Kasia's disease fell on us like a bolt out of the blue. We've just started doing well. Maria changed her job to a better paid one. I was promoted. Everything was alright. We even went on our first holiday abroad. Then this. Our situation changed completely. First, additional expenses for doctors, individual therapy. Then Maria quit her job. She had to take care of Kasia and Wiktoria. I think Wiki has suffered the most. We can't afford everything now. She keeps saying her friends have this or that. When we tell her that we cannot afford it, that Kasia ... she only inhales and says that she understands. But does she really? ... (Stanisław speaks with concern in his voice).

Jolanta and Andrzej (Married for 17 years):

The disease has hit our financial security. We are not a wealthy family. We have no savings. We go by somehow. However, when Kuba fell ill, it was a nightmare. Everywhere, help only for money. Without money, we had to wait in long lines. A parent will do anything for a child. We overborrowed. But we made it. It's better with Kuba. He's not so aggressive, he's taking his medicines regularly. It was worth it. Only now we pay back. Little by little. We live frugally (Andrzej says proudly). Our older daughter chose a school in our town so as not to multiply the costs. It's a pity. Because she could go to a better high school. She is very talented. But commuting and a boarding school cost money. We can't afford it.

The economic function was disturbed by the child's illness. Their standard of living has dropped significantly. Families spend part of their earnings on treating the child and all related things to the child's health. The other children feel these effects. The effects often influence their life choices. Although for a sick child, this function turned out to be very important. It received economic support in a difficult situation. Thanks to this support, the patient's health improved.

\subsection{Disorders within the care and educational function}

This function allows you to meet the needs that appear in everyday life, i.e. hunger, thirst, cleanliness, „shelter” or clothing, etc., as well as thanks to it family members who cannot act independently, which is caused by, for example, age, illness, disability etc. can count on being taken care of and providing for their needs. In a properly functioning family, members should feel good because of meeting all their needs, including living and caring, that is needed - generally being fulfilled.

Małgorzata and Janusz (Married for 14 years):

I think we are taking good care of our Aneczka. She has been suffering from depression for 3 years. She was diagnosed quickly. We realized immediately 
that something was happening. She was acting weird. We're glad it went so smoothly. We have read that people have been unable to diagnose their child's symptoms for years as depression and the parents feel helpless. Our daughter loves us and we love her very much. We take care of her. She often tells us that she feels safe with us. During the beginning things were different. We only have her. And she only has us

Joanna and Ryszard (Married for 21 years):

The family is a community. We think so, ma'am. So we have to support and give support to others. And when the disease runs in the family, we fight together. I think it's educational for our other children. We have four of them. Let them learn that if something happens to them, they can count on us. I think that's the most important thing. That we can count on each other. The kids help a sick brother. They are more empathetic. We learned a lot from this disease. About ourselves as well. And I think that if it were a test, we would pass it perfectly. Although it is not simple and easy.

As can be concluded from the narratives of the respondents, this function was not particularly disturbed. On the contrary. It has done its job. Not only the family supported the sick member, but also fulfilled an educational role. The function taught children empathy. This difficult family history also showed its members that they can count on their relatives in any situation. It also increased their sense of security and solidarity.

\subsection{Disorders within the socialization function}

By using this function, young people get to know and learn the attitudes surrounding their loved ones. Children become like a reflection of their parents who live in a given society. In addition, parents show their descendants socialization aspects, i.e. language, patterns of behavior in a given environment, moral principles and culture. Therefore, thanks to this function, new members learn about the norms that apply in a given society or environment. The child learns the ways of realizing what is valued and what is accepted in a given culture as a way of relating to other people, nature, culture, science. The family, fulfilling socialization functions, teaches, for example, forms of behavior at the table, in the cinema, in the theater, on the street, on the bus, at the office, during meetings with friends, during family gatherings. It also teaches order in and around one's own home, and thus in the future workplace. All these skills, thanks to everyday contact with adults who participate in many groups and social situations, are taken over by children and adolescents before they go to school, work, cinema or theater. By formulating requirements and expectations as well as some orders and prohibitions towards 
all family members, the process of socializing norms of conduct is carried out, i.e. learning what should be done and what should be avoided and where to direct one's interests towards.

Barbara and Mateusz (Married for 18 years):

Everything was subordinated to Wera (Weronika) and her illness. The whole world has turned upside down. As it dragged on, the children, and mothers of three, said: you have us. Why do you only think about her. We knew we should take care of all the children, but we couldn't do otherwise. The whole family suffered from it. We did everything with Wera's disease in mind. Now I can see how it has had a great impact on other children. They say differently, they behave differently. They are nervous like us and exhausted. I don't think their suffering made them noble. They hold a grudge against us (Mateusz says with deep regret in his voice).

Karolina and Marek (Married for 11 years):

We have two children. Year after year. When Michaś fell ill, our life changed completely. And we have changed. You know, we even talked to each other differently, we were nervous, we started shouting at each other. We quickly noticed that Ignaś, our younger son, was also changing. He begins to do as we do, the teacher in school began to complain about him. He's so well behaved, so polite, and now so nervous and quick-witted. Michaś is sick, not Ignaś (Karolina says cryingly). We began to fear that he might be sick as well. We went to the therapist and we heard that he was learning this from us. On one hand, we felt relieved, on the other hand, we were afraid that we were changing so much. Everybody.

Jadwiga and Roman (Married for 19 years):

We are both educated. We are humanists. We love theater, opera, cinema and shows. We were frequent visitors to such events. We are known in the artistic environment. However, when Franek fell ill, everything changed. Life was subordinate to him. This affected not only us but our children as well. We willingly introduced them to our world. We have seen them develop, even flourish, under his influence and... (Jadwiga sighs), we stopped everything. We rarely leave now. We stopped trying to have kids. Our life has changed completely.

In this function, the family undergoes the greatest transformation under the influence of the child's illness. Stress, frustration, and the inability to deal with emotions affect all family members. Their lifestyle, forms of communication and 
expression of emotions are changing. When there are small children in the family, they adopt new patterns of social behavior most quickly and without reflection. The process of introducing culture into the world is also changing. Parents cease these activities under the influence of the disease. They change their lives, limit their activities to care over a sick child. Not everyone is aware of these changes. Often only people from the outside (from outside the circle of family life) can capture these changes and help them consciously control them.

\subsection{Disorders within the psychological function}

This function provides family members with adequate mental development as well as all basic hygienic aspects, i.e. sense of security. Thanks to the function, family members feel fulfilled and the feeling of medicine and fear of failure are alien to them. The psychological function consists of shaping an emotionally mature and mentally balanced person. The family fulfills the task both towards society, ensuring its good mental health, and towards its members by satisfying the need for security, a sense of stability, belonging, and emotional bond, and also creates conditions for the development of the personality of its members. A properly functioning family satisfies each other's needs for love, close contact, understanding, recognition and respect. The psychological function strengthens the integrity of marriage and family.

Julia and Janusz (Married for 15 years):

At the culmination of Dorothy's illness, we felt very distressed. We felt mentally and physically exhausted. However, at the same time, we were deeply convinced that Dorothy feels our support and has a sense of security, despite her illness. This gave us hope that nothing else was important. At the same time, it turned out that we had completely forgotten about her brother. He became weepy and distracted. He still wanted us with him. When we wanted to leave him with our grandparents to take care of Dorothy, he clung to Julia like a tick and cried. It was impossible to calm him down. The therapist we went to said he felt shaky and didn't feel secure/ safe. Do you see this paradox? When Dorothy's got them, the feeling of security and feeling safe, he was losing both.

Monika and Jacek (Married for 19 years):

Antek's disease had a bad effect on our family. We crashed completely. Mostly mentally. Monika fell apart completely and so did the kids. In the beginning, we all walked and cried in the corners. We were helpless. He was acting so strange. Once he was quite lethargic and it was impossible to keep in touch with him. Other times he would scream for no reason and be aggressive. We 
didn't understand it at all. It broke us apart. However, since we have help from the counseling center, it's gotten a bit easier for us.

During the interview, all respondents emphasized disorders in this family function. They had a hard time dealing with their emotions, they felt very broken apart. The hardest part was for those who had no outside help. However, parents often emphasized that although their healthy children had a shaky sense of security due to a difficult situation, they were deeply convinced that they gave their ill child a sense of security. They often saw it as a paradox.

\section{Conclusion}

The family is the smallest and at the same time a very complex social structure. This is the first group we enter because we do it the moment we come into the world. It is thanks to the family that larger and more complex social structures are created. The family is also an investment from which we draw all our lives. As a family, we are a connected vessel system. A change in one vessel changes the other. Each family has its own individual, specific style, way of life within the family, way of expressing feelings, ideas, showing mutual understanding and attitude towards other people from the outside.

The research shows that all family functions were disturbed by the child's disease. These disorders are mainly seen in the functioning of healthy family members. Illness is a difficult situation for them. However, from the point of view of an ill child, however, the family performs most of the functions properly. The child feels safe, is cared for, economically secured.

A disease that occurs in the life of a family is a difficult situation. It requires the reorganization of the current lifestyle of the family. The appearance of a chronic disease is a special situation. A child's illness is an event in the life of the family, it disturbs its various spheres, requires mobilization and necessary changes. It also affects the relationship between the child and parents and other family members. Sometimes it disorganizes the life of the family and leads to its breakdown, but it can also be a factor that unites it and mobilizes it to cooperate in the interests of the well-being of a sick family member (Woynarowska 2010, p. 11). Managing oneself in this situation is not possible without various forms of supporting the child and family by specialists and appropriate social institutions (Maciar, 2006, p. 7).

The Covid-19 pandemic has increased the already huge mental health problems around the world. On the 13th of May 2020 the United Nations (UN) published a report on the relationship between Covid-19 and mental health. In the report the UN warns us, that before the Coronavirus became a problem, statistics regarding mental health problems around the world, especially in children and teenagers were already really tragic and that the global pandemic only exponentially increases the mental health problems in children and young adults. In the past couple of 
months there have been actions taken the goal of which is to help support people in groups of high risk and to give help to people in need suffering with mental health problems, the scale to which this problem arose is unbelievable, which causes this problem to remain unsolved as not everyone is able to receive the help they require. The main problem is the lack of funding in the promotion of mental health and care for people with mental health illnesses before the explosion of the pandemic worldwide. "The historical underfunding for mental health must be immediately fixed, so that it would help lower and decrease the mental suffering of hundreds of millions of children and teenagers, as well as lower the long term social and economical costs for society"- we read in the report (Majewska, 2020). It all holds a difficult challenge for the described generation in this article.

\section{References}

Haidt J., The Happiness Hypothesis: Finding Modern Truth in Ancient Wisdom. (2006). New York: Basic Books.

Kendall P.C. (2004). Zaburzenia okresu dzieciństwa i adolescencji. Mechanizmy zaburzeń i techniki terapeutyczne dla praktyków i rodziców. Gdańsk: Gdańskie Wydawnictwo Psychologiczne.

Kennedy Sidney H., Lam Raymond W., Nutt David J., Thase Michael E. (2010). Depresja leczyć skuteczniej. Praktyczne zastosowanie zaleceń klinicznych. Gdańsk: Via Medica Wydawnictwo.

Kołodziejek M. (2008). Depresja u dzieci i młodzieży: podstawy teoretyczne, psychoterapia poznawczo-behawioralna. „Psychoterapia”, 2 (145).

Lorens R., Uczeń y... uczeń Z... uczeń All Inclusive... (2020). Dostępny na: https://www. mac.pl/aktualnosci/uczen-y-uczen-z-uczen-all-inclusive (otwarty: 3.05.2021).

Majewska M. (2020). Pandemia COVID-19: niezbędne sa inwestycje na rzecz zdrowia psychicznego [RAPORT ONZ]. „Puls Medycyny”. Dostępny na: https://pulsmedycyny.pl/ pandemia-covid-19-niezbedne-sa-inwestycje-na-rzecz-zdrowia-psychicznego-raport-onz-991229.

Maciarz A. (2006). Dziecko przewlekle chore. Opieka i wsparcie. Warszawa: Wydawnictwo Akademickie Żak.

Rabe-Jabłońska J. (2004). Zaburzenia afektywne u dzieci i młodzieży. W: Namysłowska I. (red.). Psychiatria dzieci i młodzieży. Warszawa: Wydawnictwo Lekarskie PZWL.

Spence S.H., Reinecke M.A. (2005). Rozumienie, zapobieganie i leczenie depresji u dzieci i młodzieży. Podejście poznawcze. W: Reinecke M.A., Clark D.A. (red.). Psychoterapia poznawcza w teorii i praktyce. Gdańsk: Gdańskie Wydawnictwo Psychologiczne.

Wielgus A. (2017). Depresja w rodzinie. „Studia Bobolanum”, nr 1.

World Health Organisation. Depression. Dostępny na: http://www.who.int/mediacentre/ factsheets/fs369/en (otwarty: 20.05.2018).

Woynarowska B. (2010). Uczniowie z chorobami przewlekłymi. Jak wspierać ich rozwój, zdrowie i edukację. Warszawa: Wydawnictwo Naukowe PWN. 
Wójcik M. (2016). Pokolenia X, Y, Z - różnice w zachowaniu. Co to oznacza dla marketera? Dostępny na: https://marketingibiznes.pl/marketing/pokolenia-X-y-Z-roznice-w-zachowaniu-co-to-oznacza-dla-marketera/ (otwarty: 29.04.2021).

Ziemska M. (1980). Rodzina i dziecko. Warszawa: Państwowe Wydawnictwo Naukowe.

\section{OBJAWY DEPRESJI U DZIECI Z POKOLENIA „PŁATKÓW ŚNIEGU” I ICH WPEYW NA FUNKCJONOWANIE CAŁEJ RODZINY. BADANIA NARRACYJNE WSPÓŁCZESNYCH RODZIN}

Streszczenie: $\mathrm{W}$ artykule analizuję problem zdrowia psychicznego dzieci z pokolenia „płatków śniegu”. Przedmiotem artykułu jest problematyka depresji dziecięcej dotykająca cały system rodzinny. Przedstawiono główne objawy tej choroby z uwzględnieniem ich wpływu na relacje rodzinne. Przypomniano główne funkcje rodziny, które stanowiły podstawę do analizy testów narracyjnych. Dużo uwagi poświęcono opisowi wpływu depresji na życie całej rodziny, w tym na małżeństwo, kontakty z dziećmi, kontakty społeczne, zmiany w aktywności rodziny i sytuacji materialnej, a także reakcje emocjonalne członków rodziny. Analiza testów narracyjnych pokazuje reakcje rodziny na chorobę dziecka.

Słowa kluczowe: pokolenie „płatków śniegu”, problem zdrowia psychicznego, choroba, depresja, rodzina, radzenie sobie z depresją, skutki depresji w rodzinie, badania narracyjne. 